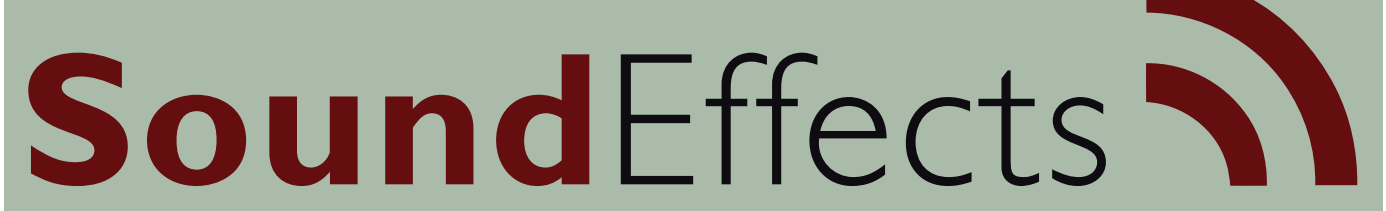

An Interdisciplinary Journal of Sound and Sound Experience

\title{
Darryl Cressman
}

\section{Acoustic architecture before science}

The case of Amsterdam's Concertgebouw

\section{Dr. Darryl Cressman \\ Assistant professor of philosophy, \\ Faculty of Arts \& Social Sciences, Maastricht University. \\ darryl.cressman@maastrichtuniversity.nl}




\begin{abstract}
Concert halls are designed for attentively listening to music. To guarantee that the listening experience mediated by these buildings is acoustically correct, architects rely upon mathematical formulas to measure and predict how a building will sound. Armed with these formulas, they are able to experiment with unconventional concert hall designs without compromising the acoustics. The achievements of modern architectural acoustics are a valorisation of the mathematical formulas used to predict acoustics. Indeed, the development of a predictive theory of architectural acoustics by Wallace Sabine in 1900 has been celebrated as the beginning of a new era of understanding sound and acoustic design. However, overlooked in this scientific triumphalism are the aesthetic standards that shape the acoustic design of buildings for music. Sabine's formula transformed our understanding of how music behaves in an enclosed space, but it did not change our understanding of how music should sound in these spaces. In this paper I explore these points through a history of the acoustic design of Amsterdam's Concertgebouw, which opened in 1888. Through an examination of the history of the acoustic design of the Concertgebouw, I describe the process of acoustic design prior to Sabine as a process of aural imitation. With this concept I reconceptualise the history of acoustic architecture to better recognise, first, how Sabine's theory is simply a more effective form of aural imitation, and second, how the quantification of sound has led to a subjective idea of good sound becoming fixed as an objective measure of what good sound should be.
\end{abstract}

\title{
Introduction
}

The three best concert halls in the world, according to acousticians, critics and music lovers, are Vienna's Grosser Musikvererinssaal, Boston Symphony Hall and Amsterdam's Concertgebouw (Beranek, 2004, p. 425; Newhouse, 2012, p. 10; Winckel, 1974, p. 180). What makes these the best is their sound, proving that a beautiful concert hall with horrible acoustics can never be redeemed. Other examples can attest to this. In the lead up to the opening of Montreal's La Maison Symphonique in 2011, a newspaper headline read, 'It looks good. But how will it sound?' The article went on to claim that 'the promise of better acoustics is the whole raison d'être' for this building (Everett-Green, 2011). Similarly, the motivation for Frank Gehry's Walt Disney Concert Hall in Los Angeles (opened in 2003) was the 'dreadful acoustics' of the Dorothy Chandler Pavilion, the home of the Los Angeles Philharmonic Orchestra since 1964. For Gehry, good acoustics would be the defining quality of his concert hall: 'no aspect of the scheme obsessed him so much' (Filler, 2003). And in the case of New York's Philharmonic Hall at Lincoln Center, which opened in 1962, New York Times music critic Harold C. Schonberg introduced readers to terms like reverberation and reverberation time, writing it is upon these factors that the fate of Phil- 
harmonic Hall will really rest' (Schonberg, 1962). Unlike La Maison Symphonique and the Walt Disney Concert Hall, Philharmonic Hall was considered an acoustic disaster and its design was continually revised and renovated in consultation with acousticians, until finally its interior was completely rebuilt and the building was reopened as Avery Fisher Hall in 1976 (Jaffe, 2010, p. 26).

Given this expectation of acoustic excellence, for the patrons and the architect of Amsterdam's Concertgebouw, which opened on April 11, 1888, the days leading up to the inaugural concert must have been tense. Not only were there constant worries about money, they had no idea how the hall would sound. This is what makes the Concertgebouw acoustically interesting - it was designed and constructed prior to the development of a formula that could accurately predict how a building would sound. It was only in 1900 that architectural acoustics became subjected to scientific measurement and prediction, and so for the patrons and the architect of the Concertgebouw there must have been a tense uncertainty that would be unimaginable today.

The formula that first endowed architects with the ability to accurately predict how a building would sound was called the reverberation equation and was developed by Harvard physicist Wallace C. Sabine in 1900. As its name implies, this theory measures the time it takes for sound in an enclosed space to decay and disappear completely. Sabine figured out a mathematical formula which explains that reverberation time is directly related to the room's cubic volume (if the room is twice as big, it is twice as reverberant) and inversely related to the amount of sound absorbing material in the room (increase the absorption, and the reverberation decreases), and he complemented this theory with a list of popular building materials organised according to their degree of sonic absorbance (Beranek, 2004, p. 93; Thompson 2002, pp. 35-41). ${ }^{1}$ With his formula in hand, Sabine discovered that the ideal reverberation time for a concert hall designed for symphonies from the Romantic canon (from about 1820 to Mahler's death in 1911), measured at mid-frequency in a full hall, is between 1.9 and 2.2 seconds. ${ }^{2}$ In the classical period (1750-1820) a shorter reverberation time, about 1.5 to 1.7 seconds, was desirable. In this period listening became more attuned to non-notational elements like tone and feeling, but was still predominantly oriented towards identifying the parts that made up the whole, reflecting a style of music where independent musical ideas can be identified as they come together, as in the symphonies of Mozart and Haydn. In the Romantic period it was not necessary to separate out each musical detail. As composers experimented with increasingly larger orchestras, the musical details were not as important as the overall impression of the sound. In buildings designed for the performance and reception of symphonies of the Romantic period, like the Concertgebouw, acoustic success is achieved by maximising the fullness of tone, not the clear definition of each musical idea (Beranek, 1962, pp. 8-13). 
The significance of Sabine's reverberation equation and its application to the design of Boston Symphony Hall, which opened in 1900 and was the first concert hall designed in line with scientific principles, has been well documented by historians and acousticians (Beranek, 1962; Forsyth, 1985; Jaffe, 2010; Thompson, 2002). For these writers, Sabine's theory and its successful application to the design of Boston Symphony Hall is a major event in the history of architectural acoustics, marking the beginning of a distinctly modern era of acoustics and concert hall design by virtue of the ability to scientifically predict and control acoustics. One of the characteristics of this historical narrative is a divide between the modern era of acoustic design and the pre-modern era that preceded Sabine. This idea, that prior to Sabine concert hall acoustics were the product of myth, superstition and luck, is emphasised through anecdotes that draw attention to non-scientific forms of acoustic knowledge. The first of these comes from Vitruvius's De Architectura (15 BC), in which he encourages architects to embed bronze 'sounding vessels' in theatres as an aid to good acoustics. Throughout Antiquity and the Middle Ages Vitruvius' suggestions were not unknown to architects, confirmed by acoustic vases found embedded in the naves and choirs of medieval European churches (Baumann, 1990). Leo Beranek mentions that prior to Sabine some architects believed that a concert hall should be lined with thin wood because wood acts as a resonator to enhance a violin's sound, and so a thin layer of wood would enhance the sound inside a concert hall (Beranek, 1962, p. 8). ${ }^{3}$ Emily Thompson also invokes stories of sonic analogy, noting that some architects believed that because a bell was a sonorous object, a bell-shaped hall would be equally sonorous (Thompson, 2002, p. 20). Perhaps the most spectacular example, though, is Beranek's, who writes that the conductor Herbert von Karajan once asked him, 'I don't suppose you subscribe to the theory that broken wine bottles beneath the stage are good for the acoustics of a hall?' Beranek responded that he did not, countering that any broken wine bottles found when refurbishing older European halls were probably the result of workers who, during the original construction, 'flung the remnants of innumerable déjeuners into the most convenient and most hidden places' (Beranek, 1962, p. 5). These anecdotes contribute to a narrative in which Sabine's theory marks the beginning of a distinctly different era of acoustic design premised on accuracy, precision and consistency.

A history of concert hall acoustics that begins with Sabine has the benefit of revealing precise details about how sound and music are quantified and translated into design, enabling these histories to have a practical utility for acousticians and architects concerned with contemporary and future acoustic designs. However, one of the consequences of this history of the science of acoustic architecture, as the preceding anecdotes demonstrate, is a tendency to marginalise the details of the acoustic design of concert halls that were built prior to 1900. In this paper I attempt to remedy this tendency by recounting details from the history of the acoustic 
design of Amsterdam's Concertgebouw. In particular, I want to examine the process by which acoustic design was guided by aural imitation. Aural imitation, as I use the term, refers to the practice of imitating the sound of halls in which music sounds best. In the conclusion of this paper I use this history of aural imitation to reconsider the history of architectural acoustics and propose a history where Sabine's scientific rendering of acoustic architecture signifies a shift from acoustic standards, which are aural, to acoustic measurements, which are visual. I propose that in the case of concert halls, acoustic standards are dependent upon music culture, while acoustic measurements are dependent upon a mathematical formula. The history of concert hall acoustics is one in which the former are quantified by the latter. If we consider the concert hall an aural medium, that is, a medium of musical sound, then the shift from aural standards to visual measurements has had the effect of successfully fixing a subjective acoustic standard (a 1.9-2.2-second reverberation time) into an objective measure of what 'good' sound is.

\section{The history of the acoustic design of the Concertgebouw}

The history of the Concertgebouw began in 1881 with an article that appeared in the newspaper De Amsterdammer demanding 'a serious attempt to build a temple dedicated to musical performances' (Hayward, 1881). ${ }^{4}$ Written by G.C.C.W. Hayward, this article drew attention to the fact that with the upcoming demolition of the Parkzaal (Park Hall) there would be no adequate venue for orchestral concerts in Amsterdam. 'Imagine Berlin, Vienna, or Paris without a concert hall!' To the reader of De Amsterdammer in 1881 this comparison probably seemed a bit ambitious. This was not lost on Hayward, though, who pointed out that there were other cities comparable to Amsterdam, like Düsseldorf, Cologne, Frankfurt and Munich, where one could find proper concert halls and, not surprisingly, superb music cultures. Of these, Hayward suggested that the ideal model for Amsterdam should be Düsseldorf's Tonhalle. The Tonhalle was a large structure that contained within it a concert hall, the Kaisersaal, which opened in 1865 and was destroyed in 1942. It followed the rectangular, or shoebox, design with a capacity of 2,820 people and two large galleries/balconies on each side (Lansink, 1978, p. 36; Clement 2001). The Tonhalle, Hayward wrote, was perfect in its simplicity and austerity, and without excessive luxury it contained a spacious concert hall with an organ alongside necessary non-musical requirements like a cloakroom and restaurant. These are mere details though. In terms that imply attentive listening and a romantic spirit of musical transcendence, Hayward described the Tonhalle as a building 'in which you can't set foot without feeling solemn, even though there's a lack of all color and gold, and everything is very simple [...] when one enters, one's mind comes to ease, which is 
necessary to experience the true enjoyment of the arts'. In 1881 it is doubtful that any music venue in Amsterdam could inspire such remarks.

Hayward's call to build a new concert hall in Amsterdam was taken up by members of Amsterdam's bourgeois cultural elite, who formed what they called a 'Temporary Committee to Build a Concert Hall' that would organise, fund and build a new concert hall (Bank, 1995, pp. 8-11; Lansink and Taat, 1978, p. 8). For these patrons there were two reasons for this decision: First, as was pointed out in De Amsterdammer article, the city's best venue for orchestral music, the Parkzaal, was going to be demolished. This would be detrimental to the state of classical music culture in Amsterdam, and as the members of the committee were great music lovers, this was a fate that they did not want for their city. Related to this, it was hoped that a new concert hall would improve Amsterdam's second-rate classical music culture. Compared to other European cities, so-called serious music was not taken very seriously in Amsterdam; orchestras were undisciplined, musical taste tended towards novelty and frivolity, and audiences attended symphony concerts to socialise, not listen (Bank and Buuren, 2004, p. 471; Lansink, 1989). For the music loving patrons who made up the committee to build a new concert hall, it was hoped that this building would elevate Amsterdam orchestras, audiences and concerts to the level of classical music capitals like Leipzig and Vienna. For this to happen, the ideals of Musical Romanticism and the bourgeois public concert had to be materialised in the spatial, visual and, perhaps most importantly, acoustic design of this building.

Initially, though, the inspiration for the design of the Concertgebouw was based on a visual experience of space. It was decided that the best approach would be to follow the suggestion of De Amsterdammer article and imitate Düsseldorf's Tonhalle. The prolific Dutch architect P.J.H. Cuypers, whose monumental buildings include Amsterdam's Centraal Station and Rijksmuseum, worked closely with the committee, consulting on all decisions concerning the location and potential design of the new concert hall. Cuypers suggested a plot of land behind the recently opened Rijksmuseum, and on September 18, 1881 the committee confidently announced that on this piece of land 'a new concert hall will rise, entirely in the spirit of the hall in Düsseldorf' (Hoogewoud, Kuyt and Oxenaar, 1985, p. 119). Following this announcement the committee sent a circular to potential investors that promoted Düsseldorf as the model for Amsterdam. The circular followed the points that Hayward had made in De Amsterdammer three months earlier: The Parkzaal no longer exists and other venues are inadequate for orchestral concerts: 'So long as The Parkzaal is not properly replaced, Amsterdam will miss out on an institution that for a city as big as ours is not a luxury, but a necessity of life'. The situation was dire and the solution obvious: A new concert hall should be built, 'a building that will equal the famous Music Hall in Düsseldorf in size and interior. There will be space for 600 performers and 2,200 people in the audience. ${ }^{5}$ The design for the new con- 
cert hall would come from a contest between five architects who were to follow an outline sketched by Cuypers. Working from a blueprint of the Tonhalle, Cuypers' first sketch followed the shoebox model with a proposed measurement of 30 metres by 60 metres. The parterre was designed to hold 1,600 seats, the galleries on the second floor could seat 800 people, and the stage would hold an orchestra of 130 musicians and a choir of up to 700 singers (Lansink, 1989, p. 70; Hoogewoud, Kuyt and Oxenaar, 1985, p. 119). ${ }^{6}$

However, doubts about the suitability of the Tonhalle emerged shortly after it was publicised as the model for Amsterdam's new concert hall. In 1882 a letter written by W.F. Thooft, a well-known Dutch composer and music critic, was published in a Dutch newspaper, forcing the committee to reconsider its rationale for selecting the Tonhalle. Having lived in Düsseldorf for five years, Thooft was quite familiar with the Tonhalle and reported that it would be an unfortunate model, as it contains 'a flaw that cannot be repaired [...] poor sound' (Thooft, 1882). This letter drew attention to a fact the committee had overlooked in championing the Tonhalle as a model for their concert hall: This recommendation was not based on acoustics. The appeal of the Tonhalle, at least from De Amsterdammer article, was its simplicity, practicality and the overall prettiness of the interior (Lansink, 1978, p. 36). In other words, Hayward used his eyes to judge the Tonhalle, whereas Thooft used his ears.

This letter, and its prioritisation of an aural perspective, had a tremendous effect on the committee. If they were serious about building a new concert hall to the standards and norms of classical music culture, they would need to prioritise acoustics. For this they had to consider concert halls other than the Tonhalle. In light of the scientific advances in acoustic architecture that occurred over the twentieth century, it is interesting to read Thooft's ideas and suggestions on this matter. He wrote that the biggest concern should be the shape of the hall. Square and rectangular rooms should be avoided, because they caused acoustic difficulties. This shape was fine for smaller audiences of about 600 people, but larger audiences required either a very long hall, which would result in a depreciation of sound quality, or the addition of balconies, which would be a dangerous acoustic experiment in a square-shaped concert hall. Thooft wrote, 'The science of acoustics is still far too uncertain to be able to point out with certainty what the causes of poor sound quality are, but one can easily assume, as in the case before us, that whether or not the architects tread with care, there are nooks and crannies in the space in front of the orchestra in which the sound gets stuck'. The solution to these problems was to concentrate on oval or circular halls. 'In the case of very large concert halls (like the one that is going to be built in Amsterdam), I think the round shape is the preferable option. Only this shape can solve the problem of combining space and quality of sound in a satisfactory way. A round room has the great advantage that even when it is big, the distance the sound has to travel remains reasonably short'. Because 
Amsterdam already had an excellent oval concert hall in the Felix Meritis building, the architect of the new concert hall should multiply the diameter of this hall until it met the requirements of the committee. Thooft offered one more suggestion for good acoustics: 'Experience has shown that the concert halls which have the best acoustics are the ones with walls that are not in immediate contact with the outside air, but have a hollow space around them'. To prove this point, Thooft noted that both the Felix Meritis and Leipzig's Altes Gewandhaus, buildings known for good acoustics, had hallways that surrounded the hall itself.

Thooft was neither an architect nor a scientist, but he was a well-known musician and critic. For the committee, this expertise and experience had a great deal of influence. In the programme for the design contest, which was sent to the architects after Thooft's letter was published, they were asked that the design of the large concert hall be oval-shaped (Lansink, 1978, p. 37; Lansink 1989, p. 74). ${ }^{7}$ Prior to the letter, the design programme followed a traditional shoebox model, and so this change must have been a shock to the committee and the participating architects. The request for an oval concert hall was, however, short lived. The design programme was again revised shortly after the 'oval hall' draft. Notably, this final programme did not specify what shape the hall should take. The only requirement, other than adhering to the size of the land, was that there should be space for 2,000 seats and the stage should hold 120 musicians and 500 singers. Thooft's influence was still present, though, as the measurements and shape of the small hall (for recitals and smaller ensembles) were to be based on the round hall in the Felix Meritis.

The acoustic concerns expressed by Thooft, and the response to these concerns, highlight the importance of the sonic experience that this building would mediate. To privilege acoustics in the design process is to bias design towards the idea that music is a serious art form that should be listened to in attentive silence. The classical music culture desired by the patrons of the Concertgebouw was to be realised in the sound of music, not in the spatial organisation of the audience or visually impressive ornamentations or design. Achieving this sound, in the era before Sabine, meant relying on individuals whose expertise was premised on aural experience. In her history of Boston Symphony Hall, Emily Thompson writes that the patron of this building routinely consulted with musicians for advice on architectural acoustics, but in the end 'preferred the counsel of scientists to that of musicians' (Thompson, 2002, p. 14). In the case of the Concertgebouw, the patrons and architectural consultants who were tasked with selecting a design took advice from a number of self-appointed experts, including critics, musicians and music lovers, experts who considered acoustics to be a musical problem and so had to rely on their ears to make decisions. In doing so their strategy for the design of the Concertgebouw was to imitate those halls in which music sounded best. 
Unlike buildings for music designed for ecclesiastical, aristocratic, economic or convivial functions, concert halls are purpose-built for attentively listening to music, which is understood to be a serious art form. Whereas Hayward associated these ideals of classical music culture with the way a concert hall looks, Thooft recognised the importance of aural imitation for this particular building type. Although Thooft's ideas about acoustics were incorrect, his ideas about aural imitation were not, and this approach to acoustic design was exploited by the architect of the Concertgebouw, A.L. van Gendt. After the Tonhalle was rejected as a suitable model, van Gendt only referred to one concert hall as a model for his design: Leipzig's Neues Gewandhaus, which opened in 1884 and was known as an acoustically superb hall in a city that was home to intelligent and refined audiences and one of the finest orchestras in the world. In 1890 van Gendt published detailed drawings of the Concertgebouw and a short essay about the building in which he claimed that it was Leipzig's Neues Gewandhaus that he sought to imitate, writing that he hoped that the Concertgebouw would become to the people of Amsterdam what the Gewandhaus was to the people of Leipzig (van Gendt, 1890). Architecturally, there are some similarities between the Neues Gewandhaus and the Concertgebouw: The heating and ventilation systems are similar; the large hall in both buildings has rounded corners; the staircases are placed in similar locations; in both buildings the small hall is placed at the back of the building and the small hall itself was meant to imitate an older hall (the Felix Meritis in the case of the Concertgebouw and the Altes Gewandhaus in the case of the Neues Gewandhaus); and finally in both buildings hallways surround the large hall. However, there is one significant difference between the two buildings: size. The Concertgebouw was much wider than the Gewandhaus (19 metres wide) and it could hold about 700 more people (1,520 to 2,200) (Lansink, 1978, pp. 39-40; Lansink, 1989, pp. 92-94; Taat, 1985, pp. 56-60). Given this discrepancy, it can be assumed that van Gendt's remark about the Concertgebouw becoming for Amsterdam what the Gewandhaus was for Leipzig was intended to draw attention to his aim of aural imitation, not architectural imitation.

\section{Conclusion: An eye for the ear - acoustic standards and acoustic measurements}

The preceding history of the acoustic design of the Concertgebouw highlights how, in lieu of a predictive mathematical formula, acoustic design was guided by imitating those halls in which music sounded best, what I call aural imitation. Working with this concept of aural imitation, it is possible to reconsider the significance of Sabine's reverberation equation. Instead of thinking of it as a break with history or the starting point of a modern science of acoustics, the reverberation equation can be considered a more effective form of aural imitation. From this perspective 
the acoustic design of Boston Symphony Hall may have been new and modern, but the actual sound of this building was not. Applied to the design of Symphony Hall, Sabine's formula was used to replicate the reverberation time of Leipzig's Neues Gewandhaus because the patron of Symphony Hall decided that music, and in particular the symphonies of Beethoven, sounded best in this hall (Bagenal, 1929, p. 756; Thompson, 2002, p. 15). Interestingly, the sound of Leipzig's Gewandhaus was meant to replicate the sound of its predecessor, commonly referred to as the Altes Gewandhaus, which opened in 1781 (Bagenal, 1929; Bagenal, 1930). Taking this history into account, the advent of modern concert hall acoustics is simply a more precise and effective form of aural imitation, the application of an acoustic measurement to replicate an acoustic standard that had endured for centuries. Acousticians Barry Blesser and Linda-Ruth Salter make this argument by pointing out that the acoustic design of Boston Symphony Hall marks the transition from humanistic theories of acoustics to an empirical theory of acoustics.

\section{Sabine's design of Boston Symphony Hall was therefore an extension of musical traditions that predated modern acoustics [...] the aural success of Boston Symphony Hall was, in part, the result of three centuries of accumulated knowledge about sound as a physical phenomenon. At the beginning of the twentieth century, Sabine transformed the basis of acoustics - from philosophy to science and engineering. (Blesser and Salter, 2007, p. 79)}

Adopting this historical perspective, Sabine's reverberation equation transformed our understanding of how music behaves in enclosed spaces, but it did not change how music should sound in these enclosed spaces. For acoustic measurements to 'work', they need to be contextualised within acoustic standards drawn from music culture. However useful the reverberation equation and other mathematical formulas are, on their own they cannot guarantee a good sounding concert hall. Measuring sound is one thing, the standard against which this measure is considered musically meaningful is something completely different. A two-second reverberation time is ideal for Romantic symphonies. This music, as architectural historian Michael Forsyth writes, has a distinctive sound: 'The blending effects of reverberance is like the brush strokes of an impressionist painting, which obscures the subject so that the onlooker is induced to project his senses and emotions into the work in order the perceive the image [...] the formally structured music of the Classical period, unlike music of the Romantic era, which predominantly expresses emotion, has reason and clarity as its basis' (Forsyth, 1985, p. 17). A two-second reverberation time only makes sense within a cultural context where symphonies that express the emotion and feelings of Romantic composers are desirable.

The case of the Concertgebouw that I presented in this paper demonstrates that before architectural acoustics was a formal science it was an aural art, dependent on acoustic standards that were verifiable through listening. Thooft did not need 
to know the reverberation time of the Tonhalle to know that when he listened to music in this hall it did not sound good. Subjected to the rigor of physics, acoustic architecture became a visual science, a set of numbers divorced from any musical context. This is a sort of McLuhan-esque substitution of the eye for the ear, where acoustic standards were made visual and translated into acoustic measurements: 'The drive towards science was, from the ancient world to the time of Bacon, a drive to extricate the visual from other senses' (McLuhan, 1962, p. 184). The shift from the ear to the eye enabled acousticians to effectively isolate sound from the context of musical meaning with little regard to how this influences compositional creativity. It is no longer necessary to ask why a concert hall needs to have a two-second reverberation time; the tools and techniques that enable this sound to be imitated ad infinitum have transformed this culturally contingent standard into an objective measure for 'good' sound.

Following McLuhan, who writes that the consequence of oral/aural cultures becoming supplanted by visual/print cultures is that the vibrancy and fluidity of linguistic meaning becomes fixed, the shift from acoustic standards to acoustic measurement has had the effect of fixing the sound of good concert halls to a reverberation time of between 1.9 and 2.2 seconds, ensuring that all concert halls are purpose-built for the symphonies of the Romantic period. The art of aural imitation has become a science, and aural imitation has become sonic homogenisation. Even as our scientific knowledge of acoustic architecture has progressed, the objective measure of a good sounding concert hall has remained fixed. Beginning in the 1960s, acousticians recognised that the sound of a concert hall is directly related to the reflecting patterns of sound waves, not the sonic absorbency of materials found within the concert hall. This means that if you can duplicate the reflection pattern of traditional halls, regardless of geometry, you can duplicate the acoustic standard of traditional concert halls (Jaffee, 2010). This has led to the design of concert halls that are visually striking, yet retain a predictable acoustic standard, including the first wrap-around hall, Berlin's Philharmonie (1963), which has a reverberation time of 1.9 seconds. After acoustics became subject to increasingly refined techniques of scientific measurement and control, the visual experience of concert hall space was considered contingent and malleable, while the acoustic experience, as it relates to reverberation, became fixed at about two seconds. That a reverberation time established more than 150 years ago is still the acoustic standard today is a testament to ideas about how orchestral music should sound. Reviewing the reverberation times of famous concert halls built between Vienna (1870) and Los Angeles (2003), it is clear that there has been a standardisation of sound across orchestral music culture: 
Philharmonie (Berlin/1963): 1.9 seconds

Sydney Opera House (Sydney/1973): 2.1 seconds

Tokyo Opera City Concert Hall (1997): 1.96 seconds

Culture and Congress Centre Concert Hall (Lucerne/1999): 1.9-2.1 seconds

Disney Hall (Los Angeles/2003): 1.85 seconds

(Beranek, 2011)

In theory, concert halls could sound very differently than they do now. This happened, slightly, in the 1920s and 1930s when the demand for larger audiences led to halls with reverberation times that fell between 1.0 and 1.5 seconds. Acoustically, the main attribute of these halls is clarity, which comes at the expense of the 'liveness' or 'envelopment' of more reverberant halls that are louder and have a fuller tone; a sort of return to the acoustic expectations of the Baroque and classical periods. Yet, it is possible to design a concert hall with a four-second reverberation time or even a five-second reverberation time. The effect of this would be that this building would be useless for the performance of symphonies composed in the nineteenth and early twentieth centuries and would end what critical musicologists interpret as concert hall hegemony - the idea that the creation of new orchestral music is stymied by the expectation that it must be like the musical works that are already displayed and revered in the concert hall museum (Burkholder, 1983). As the music director of the St. Louis Orchestra states, "it is more difficult to perform new music in a classical hall or opera house because they raise expectations of something familiar [...] the moment you go into an unusual space, unusual music doesn't sound so unusual' (Newhouse, 2012, p. 43). In buildings with a different acoustic standard, composers could begin composing new styles and forms of orchestral music to fit these new acoustics. Orchestras could be reconfigured so that the instruments that were acoustically emphasised in conventional concert halls - strings and piano - could be replaced by instruments privileged by other acoustic standards, which favour new tones. Similarly, the tempo of symphonic music could be altered to meet new acoustic standards. In short, the acoustic standard of the concert hall is purposebuilt for a particular musical sound; a new acoustic standard could engender new sounds, tempos and styles of orchestral music.

\section{References}

Bagenal, H. (1929). The Leipzig Tradition in Concert Hall Design. Journal of the Royal Institute of British Architects, 36, 756-763.

Bagenal, H. (1930). Bach's Music and Church Acoustics. Music \& Letters, 11(2), 146-155.

Bank, J. (1995). Music \& Patronage in Amsterdam. In: Mitchell (ed.), Gustav Mahler: The World Listens. Haarlem: Tema Uitgevers.

Bank, J. and Buuren, M. van. (2004). Dutch Culture in a European Perspective Vol.3: 1900 The Age of Bourgeois Culture. Translated by L. Richards and J. Rudge. New York: Palgrave. 
Baumann, D. (1990). Musical Acoustics in the Middle Ages. Early Music, XVIII, 199-212.

Beranek, L. (1962). Music, Acoustics \& Architecture. New York: John Wiley \& Sons Inc.

Beranek, L. (2004). Concert Hall \& Opera Houses: Music, Acoustics and Architecture. Springer: New York.

Beranek, L. (2011). Concert Hall Acoustics. Architectural Science Review, 54, 5-14.

Blesser, B. \& Salter, L.R. (2007). Space Speak, are you Listening? Experiencing Aural Architecture. Cambridge: MIT Press.

Bottenheim, S.A.M. (1948). Geschiedenis van het Concertgebouw: Eerste Deel. Amsterdam: Joost van den Vondel.

Burkholder, J.P. (1983). Museum Pieces: The Historicist Mainstream in the Music of the Last Hundred Years. The Journal of Musicology, 2(2), 115-134.

Clement, P. (2001). The Concertgebouw, Amsterdam, in its early years: Acoustic Design and the Resolution of Acoustic Difficulties. Nederlands Akoestisch Gennotschap, 158, 71-80.

Everett-Green, R. (2011). It Looks Good. But How Will it Sound? A Sneak Peak at Montreal's New Symphony Hall. The Globe and Mail. September 3, 2011, p. R5.

Filler, M. (2003). Victory at Bunker Hill. The New York Review of Books, 50(16).

Forsyth, M. (1985). Buildings for Music: The Architect, the Musician, and the Listener from the Seventeenth Century to the Present Day. Cambridge: MIT Press.

Gendt, A.L. van. (1890). Concertgebouw te Amsterdam. Arnhem: P. Gouda Quint.

Hayward, G.C.C.W. (1881). Concertzaal. De Amsterdammer:Weekblad voor Nederland. June 26, 1881, p. 4. Hoogewoud, G., Kuyt, J.J. and Oxenaar, A. (1985). P.J.H. Cuypers en Amsterdam. Assen: Van Gorcum.

Jaffe, J.C. (2010). The Acoustics of Performance Halls: Spaces for Music from Carnegie Hall to the Hollywood Bowl. New York: W.W. Norton \& Company.

Lansink, L. (1978). De Akoestiek van het Concertgebouw Historisch Bezien. Preludium, 36(8), 35-47.

Lansink, L. (1989). Het Concertgebouw - Een Drang tot Hooger Leven. In: van Royen (ed.), Historie en Kroniek van het Concertgebouw en het Concertgebouworkest: Deel I Voorgeschiedenis/1888-1945 (pp. 69-96). Zutphen: De Walburg Pers.

Lansink, L. \& Taat, J. (1978). Van Dolf van Gendt naar Bernard Haitink: Negentig Jaar Concertgebouw en Concertgebouworkest. Amsterdam: Het Concertgebouw NV.

McLuhan, M. (1962). The Gutenberg Galaxy. Toronto: University of Toronto Press.

Newhouse, V. (2012). Site and Sound: The Architecture and Acoustics of New Opera Houses and Concert Halls. New York: The Monacelli Press.

Schonberg, H.C. (1962). Acoustic Factor: Will Philharmonic Hall be Among the Great Ones? The New York Times. September 23, 1962.

Taat, J. (1985). Amsterdam Heeft Het Concertgebouw. Amsterdam: Het Parool.

Thompson, E. (2002). The Soundscape of Modernity: Architectural Acoustics and The Culture of Listening in America 1900-1933. Cambridge: MIT Press.

Thooft, W.F. (1882). Ingezonden Stukken: De Nieuwe Concertzaal. Algemeen Handelsblad. March 28, 1882.

Winckel, F. (1974). Space, Music, and Architecture. Cultures: Music in a Changing World, 1(3), 135-203.

\section{Notes}

1 Sabine registered the absorption coefficient of, for example, plaster on tile as .025, meaning every time sound energy encounters a surface of plaster on tile, 2.5 per cent of this energy is absorbed, while 97.5 per cent of the energy is reflected back into the room. According to Sabine's table, an open window measured 100 per cent absorbency, because an open window absorbs all sonic energy without any reverberation (Forsyth, 1985, pp. 247-250; Thompson, 2002, pp. 40-41). 
2 What I listed as the three best concert halls in the world, Boston Symphony Hall, Amsterdam's Concertgebouw and Vienna's Grosser Musikvereinssaal, have reverberation times, measured as mid-frequency in a full hall, of 1.9 seconds, 2 seconds and 2 seconds, respectively.

3 Beranek explains the fallacy of this assumption: "The sound of a violin as we hear it is produced by the vibration of its strings, which transmit energy into the belly and back of the instrument. These surfaces radiate sound in much the same way as does the lightweight paper cone of a loudspeaker; thus they must be thin, of light weight, and highly responsive to vibration. Thick heavy surfaces could not easily be set into motion by the delicate vibrating strings, and thus a loud, clear tone would not emanate from a thick-walled violin. In a concert hall, we do not want to radiate sounds beyond the walls of the hall, but rather we want to conserve the energy by keeping it inside. This required that the walls be hard and heavy, made of plaster or masonry or thick wood. Contrary to popular impression, the great concert halls and opera houses of the world contain very little, if any, thin wood on the walls and ceilings - the very best of them are lined almost entirely with heavy plaster or thick, heavy wood - materials that keep the sound inside for the enjoyment of the listener' (Beranek, 1962, pp. 8-9). For reproductions and commentary on this article, see: Bottenheim (1948, pp. 11-14); Lansink and Taat (1978, p. 8); Taat (1985, pp. 8-12).

5 Gemeente Stadsarchief Amsterdam (GAA) 1089, no. 73. Circular no. 1.

6 A copy of this design and a copy of the Tonhalle blueprint can be found in the Cuypers archive held at the Netherlands Architectural Institute (NAI), archive CUBA, no. t192.

7 Dated June 9, 1882. NAI, archive CUBA, g192. 